\section{Quando imagens passam a ser consideradas ídolos*}

\author{
LuIz JosÉ DIETRICH \\ JoRGE YeCID TRIANA RODRÍGUEZ ${ }^{* *}$
}

RECIBIDO: 15-05-15. APROBADO: 12-11-15

Resumo: Os autores refletem sobre o uso de imagens na história da religião do antigo Israel. De um contexto em que as imagens eram abundantes y seu uso aceito e normal, chegase à proibição total de imagens. Buscando as raízes da luta contra as imagens, apresentam um conceito de idolatria não tanto relacionado às imagens em si, mais como um grito no combate às injustiças, violências e desigualdades sociais.

Palavras chave: Idolatria; tradução da Bíblia; terafim; imagens de metal fundido; religião; poder e colonialismo.

\section{PARA CITAR ESTE ARTÍCULO:}

Dietrich, Luiz José y Jorge Y. Triana. "Quando imagens passam a ser consideradas ídolos". Theologica Xaveriana 181 (2016): 103-122. http://dx.doi.org/ 10.11144/javeriana.tx66-181.qipci

\section{Cuando las imágenes pasan} a ser consideradas ídolos

Resumen: Los autores reflexionan sobre el uso de imágenes en la historia de la religión del antiguo Israel. Parten de un contexto en que las imágenes eran abundantes y regularmente usadas, para pasar a su prohibición total. Al buscar las raíces de la lucha contra las imágenes, presentan un concepto de idolatría relacionado no con las imágenes en sí, sino con el combate a las injusticias, la violencia y las desigualdades sociales.

Palabras Claves: Idolatría, traducción de la Biblia, terafim, imágenes de metal fundido, religión, poder, colonialismo.

\section{When images become idols}

Summary: The authors reflect about the use of images in the history of ancient Israel's religión, from a context in which images were abundant and ussualy used, to a context in which they were absolutely forbidden. Looking for the roots of this struggle against images, the authors present a concept of idolatry, not related to the images, but to the fight against injustices, violence and social inequalities.

KeY wORDs: idolatry, Bible's translation, terafim, molten metal images, religion, power and colonialism.

\footnotetext{
* Ensaio investigativo na história da religião de Israel.

** Luiz José Dietrich: Doutor em Ciências da Religião, pela Universidade Metodista de São Paulo, UMESP. Professor adjunto do Programa de Pós Graduação em Teologia da Pontifícia Universidade Católica do Paraná, PUC PR. Correio eletrônico: luizdietrich@ig.com.br. Jorge YeCid TRIANA RodríGUEZ: Licentiatum in Scientiis Biblicarum et Archaeologiae por el Studium Biblicum Franciscanu, de Jerusalén. Docente investigador de la Corporación Universitaria Minuto de Dios. Correio eletrônico: ytriana@uniminuto.edu
} 


\section{Introdução}

As recentes mudanças nas concepçôes e na metodologia de análise da arqueologia do mundo da Bíblia estão implicando em muitas transformaçôes no modo de compreendermos a história de Israel, a história da Bíblia e a história de muitas de suas teologias e instituições ${ }^{1}$.

A nova maneira de conceber a história de Israel nos desafia a reler quase tudo o que pensávamos saber sobre as teologias do antigo Israel e também suas instituições. $\mathrm{O}$ quadro agora é muito menos linear do que imaginávamos e também mais complexo, mas ao mesmo tempo, esperamos, mais próximo da vida real, menos mitificado, menos idealizado.

\section{Caem certezas e nascem novos desafios}

No quadro que temos atualmente, a história de Israel não tem início na Babilônia, nos anos 1800 a.C., com a migração de Abraão. Porém, inicia-se bem mais tarde, entre 1500 e 1300 a.C., em Canaá. Nesta época teria acontecido a sedentarização de algumas famílias de pastores ao redor de três regiôes das montanhas centrais da Palestina: Siquém, Betel e Hebron. Na época essa região é parte do território conhecido como Canaã.

As povoaçôes destes locais guardaram e transmitiram os nomes dos patriarcas das primeiras famílias que ali se assentaram. Em Siquém, junto ao poço, guardaram-se as memórias de Jacó (Gn 33,18-19; 48,21-22; cfr. Jo 4,5.12). No santuário de Betel, transmite-se o nome de Israel como seu fundador (Gn 28,10-22; 33,20; 35,1-15). E junto ao túmulo de Macpela, em Hebron, mantiveram-se as memórias de Abraão (Gn 23,19-20). Junto às memórias dos patriarcas, as tradições também guardam os nomes das matriarcas: Lia, Raquel e Sara, Agar, entre outras.

Esses assentamentos teriam acontecido independentemente uns dos outros. $\mathrm{E}$ as famílias envolvidas provavelmente não tinham relaçáo de parentesco umas com as outras. Não sabemos muito mais detalhes sobre elas. Acredita-se que fossem de origem pastoril porque os vilarejos que originaram têm suas casas construídas formando um círculo ao redor de um espaço central, lembrando a maneira como os pastores organizavam seus acampamentos, dispondo as barracas ao redor de um centro onde as cabras e ovelhas eram guardadas nas noites ${ }^{2}$.

\footnotetext{
${ }^{1}$ Sobre isso ver mais em Finkelstein y Silbermann, A Bíblia não tinha razão, 15-41; Liverani, Para além da Bíblia. História antiga de Israel, 13-17 e 440-443; Silva, "A História de Israel na pesquisa atual", 43-87 (e também o site: http://www.airtonjo.com).

${ }^{2}$ Finkelstein y Silbermann, A Bíblia não tinha razão, 159.
} 
Mais um aspecto que fala em favor da origem pastoril dessas famílias precursoras de Israel é a proibição de comer carne de porco. Nas partes planas, onde vivia a maior parte da população de Canaã, integrada às cidades-estado, porcos eram criados e consumidos e as escavações arqueológicas nessa região encontram muitos ossos destes animais. Mas, eles estão ausentes nas partes montanhosas ${ }^{3}$.

O surgimento de Israel está vinculado à crise das cidades-Estado das planícies. Isto aconteceu entre os anos 1250-1100 a.C. Esta crise está relacionada principalmente às diversas invasóes dos chamados "povos do mar", guerras entre cidades e secas prolongadas. As guerras traziam sofrimentos e perdas terríveis para as famílias camponesas. Elas viviam, tinham suas casas, animais e plantaçóes fora das muralhas, e eram as primeiras a sofrer os ataques. Uma sequência de invasôes e guerras teria causado um fluxo migratório das planícies para as montanhas. E os pequenos vilarejos, estabelecidos pelas primeiras famílias de pastores, cresceram ao redor de Siquém, Betel e Hebron e originaram as primeiras tribos, possivelmente dando início ao povo que na estela erigida pelo faraó Merneptah, de 1213-1203 a.C., é chamado de "Israel".

Esta estela é o testemunho mais antigo do nome "Israel", e refere-se a um povo que vivia na região montanhosa central de Canaã. A forma como a palavra "Israel" está escrita na estela pode ser indicativo de povos nômades, seminômades, mas neste caso provavelmente esteja se referindo a pequenos vilarejos de camponeses que não haviam constituído cidades com muralhas ${ }^{4}$. Provavelmente tratava-se já das tribos de Efraim, Benjamim e Manassés. A regiáo de Hebron talvez fosse parte de Benjamim, ou talvez já existisse a tribo de Judá, sendo Hebron então o centro da tribo de Judá.

Certamente foram estas três, ou quatro, tribos que, por volta dos anos 1050 a.C. formaram a monarquia do Benjaminita Saul (1Sm 9,1-2). As dimensões bíblicas da jurisdiçấo de Saul vão de Jabes de Galaad, a poucos quilômetros no outro lado do Jordão (1Sm 11,1-15; 31,8-13), até a localidade de Carmel, alguns quilômetro ao sul

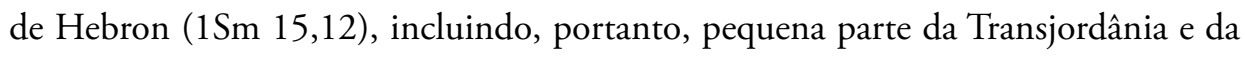
região montanhosa da Palestina central ${ }^{6}$.

${ }^{3}$ Ibíd., 169.

${ }^{4}$ Kessler, História social do Antigo Israel, 56.

${ }^{5}$ Em Jz 5, o chamado cântico de Débora, considerado um dos trechos mais antigos da Bíblia, não menciona Judá. Ver Siegfried, Historia de Israel en la época del Antiguo Testamento, 59-150; e Bailāo, Shiloh. O messianismo antigo, 36-64.

${ }^{6}$ Kaefer, “A Bíblia, a arqueologia e a história”, 149-166, especialmente 161-162. 
Estas três ou quatro tribos sob o comando de Saul serão a base do reino de Israel, que conhecemos como "o reino do norte". Também aqui não sabemos ao certo se a tribo de Judá já existia e era parte dos domínios de Saul. Mas, se o substrato de $1 \mathrm{Sm}$ 17, corresponde a história, o fato de Jessé, o pai de Davi, que vivia próximo de Hebron, em Belém, ter enviado alguns de seus filhos para lutar no exército de Saul (1Sm 17,12-14), permite pensar que pelo menos parte do que será o território de Judá estava dentro da jurisdição militar de Saul. Talvez fizesse parte do território de Benjamim.

O reino de Judá só se forma após Saul e seus filhos mais velhos terem sido massacrados pelos filisteus (1Sm 31). Ao retornar de seu refúgio entre os filisteus, Davi é consagrado rei em Hebron (2Sm 2,1-4). Nasce ali o reino de Judá. Bem mais modesto em quantidade de terras férteis e de homens, Judá sempre será bem menos importante na guerra, na política e na economia do que seu vizinho do norte, Israel. E assim, permanecerá quase a maior parte do tempo, à sombra do reino do norte, até a invasão assíria derrotar e desestruturar o reino de Israel em 722 a.C.

Uma das afirmaçóes mais estrondosas da nova arqueologia é a constatação de que o grande império davídico-salomônico, descrito nos primeiros capítulos de 1 Reis, jamais existiu. As escavaçóes arqueológicas feitas com os critérios científicos da arqueologia moderna, independente frente à Bíblia, não encontram nenhum vestígio do vasto e rico império descrito nos primeiros 10 capítulos de 1 Rs. Fora da Bíblia não há nenhum testemunho da existência de Salomão. Fato este que leva arqueólogos mais céticos inclusive a afirmarem que Salomão é um mito.

Fora da Bíblia, o nome de Davi aparece uma só vez. Ele é mencionado na chamada "estela de Dâ". Esta estela teria sido erigida pelo rei Hazael, de Damasco/ Aram por volta de 841 a.C., celebrando sua vitória sobre uma coalizão formada pelo rei Jorão, que governou Israel de 848 a 841 a.C., e pelo rei Ocozias, que foi rei de Judá em 841 a.C. A estela indiretamente menciona Davi referindo-se a Ocozias como rei da Bet-David, "casa de Davi" . Para a maioria dos estudiosos isto é uma prova extra bíblica da existência de Davi e do seu reino.

A constatação que hoje predomina nos estudos acadêmicos é a de que Jerusalém, a capital do reino de Judá, só será uma grande e importante cidade após a Assíria invadir, desarticular e anexar o reino de Israel aos seus domínios em 722 a.C. Até esta época Judá viveu à sombra do reino de Israel, que na dinastia de Amri (885-841 a.C.) e no governo de Jeroboão II (783-743 a.C.) alcançará grande desenvolvimento sociocultural e político.

${ }^{7}$ Sobre essa estela ver ídem, "A estela de Dâ”, 33-46. 
Jerusalém só alcançará importância política e situação sociocultural semelhante à Samaria na época de Ezequias (716-687 a.C.), quando a Assíria destruiu a capital e outras cidades importantes do reino do norte, e também devastou 46 pequenas cidades de Judá, situadas nos arredores de Jerusalém. Nesta época, Ezequias, para acolher os fugitivos das áreas atacadas, aumentou o tamanho da cidade de Jerusalém, que "passou de cinco hectares (em grande parte ocupados por templo e palácio) para sessenta hectares, e a populaçáo provável passou de 1.000 para 15.000 habitantes, no espaço de uma geração" ${ }^{\prime}$ (entre os anos 722-700 a.C.). Esses números referem-se certamente a refugiados mais ricos, acolhidos dentro das muralhas, que foram ampliadas para recebê-los, mas muitos camponeses mais pobres devem ter-se integrado à famílias camponesas fora das muralhas, nos arredores de Jerusalém.

Assim é muito provável que os refugiados do norte, mais desenvolvido, tenham trazido suas tradições já escritas, talvez entre elas algum esboço de história, que foram reorganizados e desenvolvidos agora a partir de Jerusalém pelos escribas de Ezequias e de Josias?.

Essas são algumas das consequências e desafios para a leitura e interpretação da Bíblia no que diz respeito à história de Israel e da própria Bíblia.

\section{Nova história, novas compreensões da teologia e da religião de Israel}

Mas consequências náo menos importantes e desafiantes se dão no campo da compreensão do desenvolvimento da religiáo e das teologias de Israel ${ }^{10}$. Aqui precisamos reconfigurar nosso modo de compreender a religiáo de Israel, que fez um complexo percurso do politeísmo, com uma grande diversidade deuses e deusas, locais de culto, famílias sacerdotais, liturgias, imagens, etc., para um monoteísmo, centralizado em

\footnotetext{
${ }^{8}$ Liverani, Para além da Bíblia, 195-199. Dados semelhantes são fornecidos por Finkelstein e Silberman, $A$ Bíblia não tinha razão, 29-331. Uma estimativa divergente, com números um pouco maiores, é apresentada por Schniedewind, Como a Bíblia tornou-se um livro. A textualização do Antigo Israel, 98-106. Porém este autor parece superestimar a importância de Jerusalém no tempo de Ezequias.

${ }^{9}$ Ibíd., 48-90. As tradiçôes provindas do norte são possivelmente as seguintes: as tradiçôes de Jacó/Israel, de José (seus filhos são Efraim e Manassés, nomes das duas principais tribos do norte), as tradiçōes sobre o êxodo, o "código da aliança" (Ex 20,22-23,19), a tradição do "bezerro de ouro" (Ex 32-34), as tradiçóes dos chamados juízes libertadores, dos santuários de Silo, Gilgal e Betel, de Samuel, de Saul, dos profetas Elias e Eliseu, o núcleo mais antigo de Dt 12-26, as tradiçôes dos profetas Amós e Oséias, etc., além dos "anais dos reis de Israel", e possivelmente ainda outro textos.

${ }^{10}$ Para o processo de instituição da teologia monoteísta em Israel ver Dietrich, "Quando Deus faz mal e mata”, 11-27, onde há também indicação de outras bibliografias a respeito.
} 
Jerusalém como único local de culto, controlada por uma família sacerdotal e com um código litúrgico único.

Um dos aspectos que pretendemos desenvolver mais neste texto é a questão das imagens. Até aproximadamente os anos 720 a.C., na reforma de Ezequias, as imagens eram parte dos cultos e eram muito disseminadas em Israel e em Judá, tanto no culto público, nos muitos santuários e locais de culto espalhados por todo o território, quanto no culto doméstico.

Isso pode ser visto não só a partir da expressiva quantidade de imagens encontradas pelas escavaçóes arqueológicas nos estratos deste período, mas também na naturalidade com que certos textos mencionam as imagens, e seus portadores, sem nenhuma menção de crítica em relação à posse e ao uso de imagens em cultos religiosos (Gn 31,19.34.35; Jz 17,5; 18,14-20; 1Sm 19,13-16). E também na forte proibição que é posta em vigor pela teologia oficial após as reformas de Ezequias e de Josias, por exemplo, Dt 7,25-26; 16,21-22.

\section{"Ídolo" ou imagem? A questão das traduções: fidelidade ao texto ou à doutrina?}

Em primeiro lugar faz-se necessária uma palavra sobre as traduçóes da Bíblia que temos em português e em espanhol. Em muitos casos as traduçóes apresentadas inserem no texto traduzido um caráter pejorativo, depreciativo, que rebaixa o objeto que está sendo mencionado colocando-o como algo condenável. Isso ocorre muitas vezes quando o texto bíblico hebraico refere-se a alguma imagem, a algum objeto usado normalmente no culto público ou doméstico, na fase politeísta anterior às reformas de Ezequias e de Josias. Muitas traduçóes usam ou acrescentam a palavra "ídolo" para traduzir palavras que no hebraico indicam simplesmente alguma "imagem".

Uma recente e sintética apresentação de Dany Nocquet (2012) trata do tema das imagens bíblicas de outras divindades no Antigo Testamento, indicando que o vocabulário com o qual são nomeadas e qualificadas pelos autores em seus relatos, leis e discursos, é extenso e variado. Tal vocabulário estaria ligado às técnicas da manufatura artesanal ${ }^{11}$. Dentre os termos técnicos usados encontra-se a palavra terafim, identificada 15 vezes, com o significado de estatuetas de terracota ou gravuras entalhadas, como mencionam Gn 31,19.34 y 1Sam 19,13.

${ }^{11}$ Nocquet, El Dios único y los otros dioses. Esbozo de la evolución religiosa del antiguo Israel, 39. 
Sem uma etimologia claramente definida, os terafim "estaban ligados al culto doméstico y al de los antepasados"12. Também se discute sua função. A esse respeito, de Vaux indica que cumpriam uma função oracular ou de adivinhaçâao ${ }^{13}$, associandoos ao efod e às massebot ${ }^{14}$. Porém, devido à proximidade geográfica e cultural, talvez devêssemos buscar uma compreensão mais próxima do culto aos antepassados como o que é apresentado nas religióes africanas, também apontado acima por Nocquet.

"Imagem" é uma palavra neutra, não carrega a carga negativa e condenável que possui a palavra "ídolo". Pois, especialmente no mundo católico, e também no mundo das religióes afro-brasileiras, qualquer pessoa pode dizer: "na cabeceira de minha cama tenho três imagens", mas nenhuma destas pessoas dirá: "na cabeceira de minha cama tenho três ídolos!" Também os afiliados aos terreiros do candomblé, tambor de mina, batuques, umbanda, santerias e outras religióes que fazem uso de imagens em seus cultos, não irão referir-se a estas imagens chamando-as de "ídolos". As semelhanças entre a religião no Israel pré-exílico e a sua religião é ofuscada e colocada sob o pejo da "idolatria".

O problema é que muitas de nossas traduçóes fazem isso. Acrescentam a palavra ídolo na traduçáo portuguesa e espanhola de palavras hebraicas que se referem a objetos que no texto hebraico são tratados de maneira natural, neutra, como imagem.

\section{Alguns exemplos da tradução de Gn 31,19 em Bíblias em português}

\begin{tabular}{|l|l|}
\hline BÍBLIAS EM PORTUGUÊS & TRADUÇão DE GN 3 I,I9 \\
\hline Bíblia de Jerusalém (BJ) ${ }^{15}$ & $\begin{array}{l}\text { "Labão fora tosquiar os rebanhos e Raquel } \\
\text { roubou os idolos domésticos que pertenciam a } \\
\text { seu pai." }\end{array}$ \\
\hline A Bíblia da CNBB ${ }^{16}$ & $\begin{array}{l}\text { "Como Labão tinha ido à tosquia das ovelhas, } \\
\text { Raquel roubou as estatuetas dos idolos de seu } \\
\text { pai”. }\end{array}$ \\
\hline
\end{tabular}

\footnotetext{
${ }^{12}$ Ibíd., 41.

${ }^{13}$ De Vaux, Instituciones del Antiguo Testamento, 456.

${ }^{14}$ Ibíd., 458.

${ }^{15}$ Editora Paulus, Bíblia de Jerusalém.

${ }^{16}$ Conferência Nacional dos Bispos do Brasil, Bíblia sagrada.
} 


\begin{tabular}{|l|l|}
\hline $\begin{array}{l}\text { Tradução ecumênica da Bíblia } \\
(\mathrm{TEB})^{17}\end{array}$ & $\begin{array}{l}\text { "Laban tinha ido tosquiar o seu gado, e Raquel } \\
\text { roubou os idolos que pertenciam a seu pai." }\end{array}$ \\
\hline Bíblia de Estudo Almeida ${ }^{18}$ & $\begin{array}{l}\text { "Tendo ido Labão fazer a tosquia das ovelhas, } \\
\text { Raquel furtou os idolos do lar que pertenciam } \\
\text { a seu pai." }\end{array}$ \\
\hline $\begin{array}{l}\text { A Nova Versão Internacional } \\
(\mathrm{NVI}) \text { Bíblia de Estudo } \\
\text { Arqueológica }\end{array}$ & $\begin{array}{l}\text { "Enquanto Labão tinha saído para tosquiar } \\
\text { suas ovelhas, Raquel roubou os idolos do clã.. }\end{array}$ \\
\hline $\begin{array}{l}\text { Bíblia Sagrada Ave Maria, edição } \\
\text { de estudo }{ }^{20}\end{array}$ & $\begin{array}{l}\text { Labão tinha ido tosquiar o rebanho, e Raquel } \\
\text { roubou os terafins que pertenciam a seu pai. }\end{array}$ \\
\hline \begin{tabular}{l} 
Nova Bíblia Pastoral ${ }^{21}$ \\
\hline
\end{tabular}
\end{tabular}

No entanto o versículo hebraico não tem aqui uma palavra que possa ser traduzida como "ídolo". O texto menciona a palavra terafim, e o faz com a maior naturalidade. Terafim era o nome dado às imagens de deuses domésticos ${ }^{22}$, que muito provavelmente eram os ancestrais divinizados de cada família, eram os Elohim, das famílias. Cada família tinha os seus Elohim (cf. Gn 31,53). Não há nessa narrativa nenhum vestígio de crítica à posse destas imagens e ao seu uso nos cultos familiares. No caso de Raquel nem sequer o ato de roubar é condenado explicitamente! Para os autores da narrativa estas imagens eram conhecidas, muito comuns e de uso corriqueiro. Não há uma explicação sobre elas e nem são consideradas ídolos.

O fato de muitas de nossas traduçôes traduzirem a palavra terafim, do hebraico para o português, com a expressão "ídolos" (conforme tabela acima) revela que os tradutores assimilaram as proposiçóes das reformas de Ezequias (+ 720 a.C.) e de Josias

\footnotetext{
${ }^{17}$ Edições Loyola, Bíblia. Tradução ecumênica.

${ }^{18}$ Sociedade Bíblica do Brasil, Bíblia de estudo Almeida.

${ }^{19}$ Editora Vida Nova, Bíblia de estudo arqueológica NVI.

${ }^{20}$ Editora Ave Maria, Bíblia sagrada Ave Maria. Edição de estudo.

${ }^{21}$ Editora Paulus, Nova Biblia pastoral.

${ }^{22}$ Gessenius, Hebrew-Chaldee Lexicon to the Old Testament, 875; Koehler e Baumgartner, The Hebrew \& Aramaic Lexicon of the Old Testament. The New Koehler-Baumgartner, 4, 1794-1796.
} 
(+ 620 a.C.), e as têm como verdadeiras revelaçóes da vontade de Javé. E as usam de forma retroativa, em tradições que podem ser anteriores às reformas de Ezequias e de Josias ${ }^{23}$.

\section{Exemplos de traduções de Gn 31,19 em Bíblias em espanhol}

\begin{tabular}{|l|l|}
\hline BÍBLIAS EM ESPANHOL & TRADUÇÃO DE GN 3I,I9 \\
\hline Nueva Biblia de Jerusalén & $\begin{array}{l}\text { Aprovechando que Labán había ido a } \\
\text { esquilar sus ovejas, Raquel robó los idolos } \\
\text { familiares que tenía su padrét. }\end{array}$ \\
\hline Biblia Del siglo de oro (Reina Valera) & $\begin{array}{l}\text { Como Labán había ido a trasquilar sus } \\
\text { ovejas, Raquel hurtó los idolos de su padre. }\end{array}$ \\
\hline Biblia de estudio Dios habla hoy & $\begin{array}{l}\text { Mientras Labán fue a otra parte a tras- } \\
\text { quilar sus ovejas, Raquel le robó sus idolos } \\
\text { familiares. }\end{array}$ \\
\hline Biblia de América & $\begin{array}{l}\text { Mientras Labán se había ido a esquilar sus } \\
\text { ovejas, Raquel robó los idolos familiares de } \\
\text { su padre. }\end{array}$ \\
\hline Biblia para el pueblo de Dios & $\begin{array}{l}\text { Mientras Labán se había ido al esquileo de } \\
\text { sus ovejas, Raquel robó los idolos familiares } \\
\text { de su padre. }\end{array}$ \\
\hline Biblia de nuestro pueblo & $\begin{array}{l}\text { Labán se marchó a esquilar las ovejas y } \\
\text { Raquel robó los amuletos de su padre. }\end{array}$ \\
\hline Biblia Nácar-Colunga & $\begin{array}{l}\text { Labán había ido al esquileo de sus ovejas y } \\
\text { Raquel robó los terafim de su padre. }\end{array}$ \\
\hline
\end{tabular}

Observa-se praticamente um consenso na tradução do termo como "ídolos familiares" (NBJ, Dios Habla Hoy, Pueblo de Dios y la BA). A BSO os denomina como "ídolos del padre", que neste caso seria o chefe do clá, referindo-se então aos ídolos da

\footnotetext{
${ }^{23}$ Deve-se observar aqui que a tradução de "terafim" como ídolos, já ocorre na Septuaginta ( $\varepsilon$ ǐ $\left.\delta \omega \lambda \alpha\right)$ e também na Vulgata (idola). E é transmitida também em dicionários, como Holladay, Léxico hebraico e aramaico do Antigo Testamento, 563. Porém a Nova Vulgata, Bibliorum Sacrorum Editio, corrige isso e apresenta a tradução theraphim.

${ }^{24}$ Deve-se mencionar que esta nova versão da Bíblia de Jerusalén, como também a versão em português citada acima, indica em nota de pé de página que o termo hebraico terafîm, significa "pequenos ídolos domésticos", e que sua posse poderia constituir "título de herança".
} 
família. A edição de Alonso Schöekel traduz por "amuletos"25. Unicamente a Biblia Nácar Colunga não traduz a expressão e prefere transliterar o original hebraico; porém remete a uma explicação em nota de rodapé, indicando que "eran los ídolos domésticos, de forma más o menos humana, conforme se depreende de 1Sam 19,13.16"26.

No caso do relato de Jacó e Labão (Gn 31), pode-se perceber uma função narrativa do termo dentro do texto. $\mathrm{O}$ assunto do roubo é seria um motivo acrescentado em redação pós-exílica, "sirve para restar crédito a Labán el arameo en cuanto adorador de otras divinidades" 27 , estabelecendo-se assim um distanciamento em relação às origens araméias de Israel, ainda que se trate de uma separaçáo amigável. Continua Nocquet indicando que se evidencia um jogo de ironia na maneira como Raquel esconde os terafim sob suas pernas e em estado de impureza ritual, fazendo mofas da autoridade paterna ${ }^{28}$.

Assim, as estatuetas resultam insignificantes e ineficazes como divindades paternas frente a unicidade de Javé. Mas mesmo essa abordagem nos permite ver que os redatores pós-exílicos náo criaram toda a narrativa, somente inseriram elementos de ironia e desprezo em uma base narrativa mais antiga.

Pede-se aqui a anuência dos leitores e leitoras para fazer um parêntesis ampliando ainda um pouco mais a discussão sobre a tradução da Bíblia, dado que este é um campo muito importante, fundamental mesmo, porém ainda muito pouco discutido e estudado nas academias sul-americanas e também nos movimentos de leitura popular da Bíblia. A influência das perspectivas doutrinárias dos tradutores e das instituições que patrocinam as traduçóes fica fortemente visível quando esse objeto de culto doméstico, "terafim", aparece ligado a um personagem importante na chamada "história da salvação".

Por exemplo, quando os textos revelam a existência de "terafim" na casa de Davi e de Micol (1Sm 19,13). Na tradução de Gênesis, em se tratando da casa de Labão, pai de Raquel, privilegia-se a perspectiva doutrinária condenando o uso de imagens no culto. Na tradução de 1 Sm 19,13, que trata de um objeto na casa de Davi, várias versôes evitam traduzir "terafim", como para proteger Davi da posse de algo condenável e não usam aqui, a palavra "ídolo".

\footnotetext{
${ }_{25}^{2}$ Porém de modo inverso traduz no v. 31 por "dioses", e em 1Sm 19,13 por "idolo familiar".

${ }^{26}$ Nácar e Colunga, Sagrada Biblia, 63. Pode-se notar que os dois casos tratam de mulheres que manuseiam os terafim e os ocultam; o que também pode ser um sinal de desprezo tal como aponta a Bíblia NácarColunga na nota mencionada.

${ }^{27}$ Nocquet, El Dios único y los otros dioses, 42.

${ }^{28}$ Ibid.
} 
Essa influência doutrinária pode ter origem na LXX ou na Vulgata, pois nelas já se mostra essa tendência:

\begin{tabular}{|c|c|c|}
\hline & $\begin{array}{l}\text { TERAFINS NA CASA DE } \\
\text { LABÃO E RAQUEL } \\
(\text { GN 3I,I9) }\end{array}$ & $\begin{array}{l}\text { TERAFINS NA } \\
\text { CASA DE DAVI E } \\
\text { MICOL } \\
(\text { ISM I 9, I3) }\end{array}$ \\
\hline Septuaginta (LXX) & $\varepsilon i \delta \omega \lambda \alpha$ & 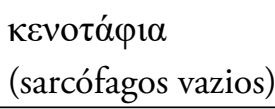 \\
\hline Vulgata (VUL) & Idola & statuam $^{29}$ \\
\hline Bíblia de Jerusalém (BJ) & Ídolos domésticos & terafim ${ }^{30}$ \\
\hline Almeida Corrigida e Fiel (ACF) & Ídolos & estátua \\
\hline $\begin{array}{l}\text { Almeida Revista e Corrigida } \\
\text { (ARC) }\end{array}$ & Ídolos & estátua \\
\hline $\begin{array}{l}\text { Bíblia Sagrada em Português } \\
(\mathrm{BRP})\end{array}$ & Ídolos & estátua \\
\hline $\begin{array}{l}\text { Sociedade Bíblica de Portugal } \\
(\mathrm{SBP})\end{array}$ & $\begin{array}{l}\text { Imagens dos idolos } \\
\text { domésticos }\end{array}$ & $\begin{array}{l}\text { Ídolo protetor da } \\
\text { casa }\end{array}$ \\
\hline $\begin{array}{l}\text { NBJ, Dios habla hoy, Pueblo de } \\
\text { Dios, BA }\end{array}$ & Ídolos familiares & Ídolos familiares \\
\hline BSO & Ídolos del padre & Uma estatua \\
\hline Biblia para e pueblo de Dios & Amuletos & Ídolo familiar \\
\hline Nácar-Colunga & Terafim & Lós terafim \\
\hline
\end{tabular}

Somente esses pequenos exemplos demonstram quão fundamental e importante é o estudo e o ensino das línguas bíblicas bem como as reflexôes sobre as traduções bíblicas que possuímos. Todas têm suas virtudes, mas também todas têm pontos em que precisam melhorar diante dos novos conhecimentos da história, da arqueologia e da religiáo do mundo bíblico e também do avanço de nossa consciência do outro, da outra em nossa sociedade.

\footnotetext{
${ }^{29}$ Também aqui a Nova Vulgata já corrigiu a intepretação e apresenta "theraphim".

${ }^{30}$ No caso de $B J$, e possivelmente outras, a tradução diferente pode ter ocorrido porque os dois textos foram traduzidos por pessoas diferentes.
} 
Fechando o parêntesis, e retomando o pensamento, as reformas de Ezequias e de Josias de fato irão estabelecer o templo de Jerusalém como único local de culto em todo Israel, instituirão Javé como Deus de Israel, proibirão o culto a qualquer outra divindade e também condenarão o uso de qualquer tipo de imagem que represente Javé ou qualquer outra divindade (2Rs 18,1-5; 23,4-24). Com estas reformas as imagens, mesmo as que podiam ser imagens de Javé, passam a ser consideradas ídolos, inclusive os terafim, e seu uso será condenado como crime de idolatria (2Rs 23,24).

As traduções, porém, ao colocar a palavra "ídolo", onde o texto hebraico não a possui e nem mesmo a pressupóe, na verdade estáo antecipando as coisas e criando um anacronismo que mascara e esconde o longo período politeísta com uso corriqueiro de imagens vivido por Israel antes das reformas centralizadoras. Além disso, essa mesma concepção doutrinária pode estar na raiz de pregaçôes e práticas geradoras de discriminação, intolerância e outras violências contra pessoas e religiōes que adotam imagens em seus cultos e liturgias, ainda hoje presentes em diversas formas do cristianismo.

\section{Idolatria... $\bigcirc$ que é mesmo "idolatria"?}

Esse procedimento acaba também por falsear, ou até mesmo esvaziar completamente o sentido libertador da crítica à idolatria. Pois acaba focando o peso desta crítica no uso da imagem em si. Idolatria, segundo esse raciocínio, é possuir imagens, usar imagens como representação do divino, substituir o Divino por algo que se possa ver, manipular, usar. Mas não é esse o motivo original da crítica profética às imagens na Bíblia.

\section{Pode haver idolatria mesmo sem imagens}

A crítica bíblica profética às imagens, à idolatria, tem mais a ver com o tipo de culto, de religião, que a elas estão associados. Criticam-se as imagens mais por suas funçóes e pelas consequências de certos cultos do que às imagens em si. Podendo ser possível, nesse sentido, haver "idolatria" sem necessariamente haver imagens.

Vejamos o texto do Salmo 115,4-8:

Sáo de prata e ouro os idolos deles,

e foram feitos por mãos humanas;

esses têm boca e não falam,

têm olhos e não veem,

têm ouvidos e não escutam.

têm nariz e não cheiram;

têm mãos e não apalpam, 
têm pés e não andam,

nem sua garganta produz sussurro algum.

Os idolos deles são obras de mãos humanas.

A verdadeira causa da condenação não está simplesmente no fato de as imagens - aqui sim este texto, possivelmente exílico ou pós-exílico as chama de "ídolos" ( 'atsav) - serem “de ouro e de prata...feitos por mãos humanas”, e se caracterizarem pela imobilidade e insensibilidade.....está sim no fato de essa imobilidade e essa insensibilidade também caracterizarem aqueles que fazem e confiam nas imagens. O versículo 8 do Salmo 115 diz literalmente isso: "Estão sendo, ou serão, como eles todos aqueles que os fazem e que neles confiam" ${ }^{31}$. Porém o problema não é somente a imobilidade e a insensibilidade em si.

Para compreender a profundidade da denúncia precisamos colocar o texto do Salmo diante da provável referência hipertextual a que ele está associado. As imagens, chamadas aqui de "ídolos", são apresentadas fazendo um contraponto a uma outra imagem, uma outra descrição, uma "imagem” narrativa, textual, de Deus. O Salmo faz um contraponto com a imagem de Deus apresentada no Exxodo:

Os filhos de Israel gemiam por causa da servidão. Eles clamaram, e da servidão seu grito de aflição subiu até Deus (Elohim). E Deus (Elohim) ouviu o clamor deles, e lembrou-se da aliança.... e Deus (Elohim) viu os filhos de Israel e os reconheceu.... (Ex 2,23-25).

A mesma imagem pode ser vista em Ex 3,7: "Javé disse: estou vendo muito bem (a Biblia de Jerusalém traduz: eu vi, eu vi) a aflição do meu povo que está no Egito. Ouvi seu clamor diante de seus opressores, pois tomei conhecimento de seus sofrimentos. Desci para libertá-los...”.

Pode-se notar que a descrição dos ídolos no Salmo corresponde à imagem invertida de uma atitude, como um negativo, da descrição da divindade do êxodo. No êxodo a ação da divindade se dá por sua sensibilidade para com os escravos, para com os oprimidos. A divindade do êxodo caracteriza-se por ver os injustiçados e ouvir os gemidos dos escravizados e os gritos dos oprimidos, e por agir, por não permanecer insensível e imóvel frente a isso. Vendo os injustiçados e ouvindo os clamores dos

\footnotetext{
${ }^{31}$ Nesse sentido recentemente foi traduzido ao português o livro de Beale, Você se torna aquilo que adora. Uma teologia biblica da idolatria. Porém a interpretação ali apresentada difere bastante da apresentada neste artigo, especialmente por não considerar as funçôes sociais do culto, especialmente as suas relaçóes com a justiça, a injustiça, as opressôes e desigualdades sociais.
} 
explorados frente a seus exploradores a divindade do êxodo age para libertar. Se solidariza com os oprimidos, toma partido deles, age, coloca-se em seu meio para salvá-los, para libertá-los.

Com isso estamos aptos para compreender a questão da idolatria transcendendo à questão das imagens: idolatria é todo culto a Deus -com imagens ou sem imagensque não nos torna sensíveis e solidários para com os pobres e injustiçados, que não nos faz ver as injustiças e ouvir os gritos dos injustiçados, e que não nos leva a solidarizarmo-nos com eles, a pormo-nos em seu lugar, em seu meio e a lutar com os oprimidos pela superação da opressão, das injustiças e das desigualdades.

É esse também provavelmente o sentido e o espírito das primeiras lutas proféticas, que se dirigem especialmente contra determinadas imagens.

\section{As primeiras lutas contra imagens}

Temos dificuldade de perceber isso, não só por causa das traduçóes, que às vezes nos impedem de ver Israel em seu período politeísta, com liturgias e cultos que incluíam grande diversidade de imagens, mas também porque na cabeça de muitos de nós está a ideia de que todas as imagens cultuais, de qualquer forma e material, foram condenadas desde o início da história de Israel.

Entretanto, se olharmos os textos com um novo olhar, instigados e informados pelas contribuiçôes da nova arqueologia, se tratarmos de compreender os israelitas vivendo dos anos 1500-1400 a.C. aos anos 700 ou 600 a.C. em um mundo de muita diversidade religiosa, em meio a muitos deuses e deusas, com muitos locais de culto, com uma grande diversidade de liturgias, objetos e imagens, talvez consigamos perceber que a condenação das imagens, e sua associação com "idolatria”, não começou no início da história de Israel, e que o processo que culminará com a proibição de qualquer tipo de imagem, de qualquer material, com qualquer forma, como aparece por exemplo em Dt 5,8, deriva-se da condenação de um tipo especial de imagens. E também poderemos ver que nesse processo o sentido primeiro, profético, foi deturpado. E o resultado, a condenaçáo geral de todas as imagens no contexto das reformas de Ezequias e Josias, em muitos sentidos é uma traição do espírito profético inicial.

\section{$\bigcirc$ grito profético contra as imagens}

Provavelmente o grito profético contra as imagens ecoa ainda hoje nas páginas da Bíblia naqueles versículos que condenam os "deuses de metal fundido", e os "deuses de ouro e de prata":

Vocês não farão para mim deuses de prata e deuses de ouro, vocês não farão para vocês (Ex 20,23). 
Deuses de metal fundido ('elohê massek kah) ${ }^{32}$ não farás para ti $($ Ex 34,17).

Uma proibição semelhante aparece em Lv 19,4: "Não se voltem para os ídolos nem façam deuses de metal fundido. Eu sou Javé, o Deus de vocês". Porém nesse verso já aparece a reinvindicação de culto exclusivo a Javé. Em Ex 34,17 a reivindicação de exclusividade a Javé está no contexto mais amplo dentro do bloco de Leis, que vai de Ex 34,10-2833. A exigência de culto exclusivo aparece nos versículos 12 e 13: "Não firme aliança com os habitantes da terra onde você vai entrar, porque seria uma armadilha para você. Pelo contrário, derrubem os altares deles, quebrem suas colunas sagradas e cortem suas Asserás". E claramente a exclusividade é estabelecida no versículo 14: "Não se prostre diante de outro El, porque o nome de Javé é Ciumento. Ele é um El ciumento" ${ }^{34}$. A exigência de culto exclusivo a Javé é a principal característica das reformas de Ezequias e de Josias. Sua presença nos textos revela a redação dos escribas de Ezequias e de Josias. Porém, a proibição explícita a um tipo específico de imagem, deve ser anterior às reformas. Vem de outro contexto.

Dois aspectos chamam a atenção nestes versículos:

- O primeiro é que tanto as imagens de "metal fundido" (massekah), como as de "prata e ouro" são chamadas de "deuses" ('elohê). Não recebem uma qualificação pejorativa. Não são chamadas de "ídolos", nem sequer para elas é usada uma palavra mais neutra, como ou genérica, como "imagem”. São chamadas de "deuses"! Para quem fala neste versículo, estas imagens são deuses. Como Labão, quando procura seus terafins pergunta: "porque roubaste meus deuses ('elohay)?" (Gn 31,30) Aqui também, mesmo expressando uma condenação estas imagens são ainda chamadas de "deuses" ( 'elohê). - $\quad$ E, em segundo lugar, chama a atenção que em Ex 34,17 a proibição é dirigida especificamente a um tipo de imagem. Veta somente a confecção de um tipo exclusivo de imagens. Especificamente as imagens de metal fundido (massekahah) são proibidas. E Ex 20,23 proíbe somente imagens feitas de ouro e de prata. Imagens de cerâmica, pedra, madeira ou outro material, não são proibidas.

\footnotetext{
${ }^{32}$ Tradução sugerida por Koehler e Baumgartner, The Hebrew \& Aramaic Lexicon of the Old Testament, 2, 605; Gessenius, Hebrew-Chaldee Lexicon to the Old Testament, 489; Holladay, Léxico hebraico e aramaico do Antigo Testamento, 287; entre outros.

${ }^{33}$ Ver Editora Paulus, Nova Bíblia pastoral, Ex 34,10-28 pode conter "as palavras de uma aliança feita no norte, nos tempos do profeta Eliseu e do rei Jeú (2Rs 10,16.26-28), ou no sul, pelo sacerdote Joiada (2Rs 11,17-18), ou por Ezequias ou Josias: impóem o culto exclusivo a Javé sem negar a existência de outros Deuses (v.14); pró́bem imagens de metal (v. 17); organizam o calendário das festas, direcionando os primogênitos e os tributos a Javé em Jerusalém (v. 18-26a; cfr. Dt 15,19-16,17) e proibindo ritos cananeus de fertilidade (v. 26b)".

${ }^{34}$ Versículos citados conforme a Nova Biblia pastoral.
} 
Para compreender melhor esta questão é interessante perceber que em Ex 20,22-26, uma das partes mais antigas do chamado "Código da Aliança" ${ }^{35}$, nesse trecho do código proibição de fazer "deuses de ouro e deuses de prata” está associada à proibição de fazer "altar de pedras lavradas". A presença desses versos testemunha a antiguidade das primeiras tradições que compóem o código. Sua origem é anterior às reformas de Ezequias e de Josias.

São de um tempo em que ainda se admite a existência de altares fora de Jerusalém: "Em todo lugar onde eu fizer lembrar o meu nome, virei a você e o abençoarei" $(20,24)$. Na primeira parte do código inclusive se legisla a respeito desses altares, dizendo que tipos de altares são permitidos (de terra, de pedras em estado natural) e que tipo de altar é proibido (de pedras lavradas). Percebe-se aqui a mesma especificidade da lei que pró́be deuses de ouro e de prata. Também aqui claramente se proíbe um tipo muito específico de altar.

A proibição dos deuses de ouro e de prata, e a proibição do altar de pedras lavradas, provavelmente pertencem ao marco inicial do processo de redação do Código da Aliança. Estas denúncias podem ter sido feitas em nome de Javé, mas ainda não propóem ou supóem uma centralizaçáo do culto, ou exclusividade do culto a Javé.

E quando nos perguntamos pelo lugar social de onde teriam brotado estas proibiçóes, ou por outra via, onde se encontravam os altares proibidos (de pedras lavradas), e as imagens proibidas (de ouro e de prata), somos levados a concluir que estas proibiçóes ecoam algumas das primeiras críticas da profecia camponesa (Amós, Oseías) contra o uso da religião para explorar os camponeses.

Aqui chamamos atenção para a especificidade da proibição. A proibição refere-se aos deuses de metal fundido (mase $\underline{k} a h$ ), ou deuses de ouro (zahav) e deuses de prata (qesef). Imagens de pedra, madeira ou cerâmica não são proibidas. Por que somente são proibidas as de metal? Por que não se pode fazer um "altar de pedras lavradas"? Quem possui ou pode fazer tanto imagens de ouro e prata como altares de pedras lavradas? Onde eram encontrados?

As perguntas têm a mesma resposta. Eram encontrados nas principais cidades. Talvez somente nas capitais e nas cidades com "santuários do rei" (Am 7,13). São materiais caros, precisam ser importados, ou precisam ser importados os artesãos que os façam (1Rs 5,31-32; 7,13-14). A condição para que sejam feitas é o acúmulo de

35 Sobre este texto ver o artigo de Dietrich, "O 'código da aliança'. Revisitando textos e reavivando saudades” 289-300, especialmente 298-299. 
riqueza e de poder. Esse acúmulo é feito às custas da opressão do povo camponês que vive e trabalha ao redor das muralhas das cidades. Imagens de metal fundido, de ouro e de prata, e altares de pedras talhadas são característicos do culto nas cidades, como os que a arqueologia encontrou em Beersheva, e em Dan, por exemplo.

Estes versículos ecoam os primeiros gritos dos camponeses contra o uso da religião para explorá-los. É no geral um grito contra a religião oficial das monarquias e seus centros de culto, nos quais a ostentação de altares caros e deuses de metal fundido, ou mesmo de ouro e de prata, tinham a função de legitimar a exploração das famílias camponesas (Os 8,4-5; 13,236; cfr. Lv 19,6; Dt 9,12.16; 27,15; 1Rs 14,9; Is 30,22). E Ex 34,17: "Não faça para você deuses de metal fundido", talvez seja a forma mais antiga da crítica aos deuses de ouro e aos deuses de prata.

Esse largo percurso nos mostra que no início as leis contra imagens não tinham nada a ver com a maior parte dos discursos teológicos que hoje rebaixam ou condenam as pessoas, povos, culturas e religióes que usam imagens em seus rituais de culto. As vilas camponesas no Israel pré-exílico estavam cheias de locais de culto, os "lugares altos", montículos de terra e de pedras, árvores, colunas de pedra, e também possuíam muitas imagens de pedra, madeira e cerâmica. E também muitas divindades com uma grande variedade de liturgias associadas a estas diferentes divindades e a suas respectivas áreas de atuação na vida das pessoas e vilarejos. Em suas liturgias e em seus cultos, porém, ninguém fiava mais rico ou mais pobre. Seus cultos estavam bem mais ligados às necessidades e tempos da vida concreta do que a funçóes de concentração de poder e de riqueza.

Assim, podemos perguntar: onde de fato está a "idolatria"? Num culto com diversidade de deuses e deusas e imagens, ligado à defesa e à promoção da vida, ou num culto centralizado em um só local, em um só Deus, com uma única liturgia, mas que está desligado da defesa e da promoção da vida, legitimando concentração de poder e riqueza?

\footnotetext{
${ }^{36}$ De Oseias, e também Amós, não se pode afirmar que eram politeístas, porém tudo indica que viviam em um contexto em que a diversidade de deuses e deusas, de cultos e liturgias, e o uso de imagens ainda eram algo comum e aceito (Barton e Stavrakopoulou (eds.), Religious Diversity in Ancient Israel and Judah; Zevit, The Religions of Ancient Israel. A Synthesis of Parallactic Approaches. Somos chamados a reavaliar as leituras e interpretaçôes que fazemos destes profetas, considerando os atuais dados da arqueologia e, o que a grande maioria dos exegetas já aceita, que seus textos chegaram para nós através de redações nas cortes de Ezequias e de Josias, ainda retocadas posteriormente no pós-exílio. E essas redaçóes, como se sabe estavam interessadas em legitimar a exclusividade do culto a Javé bem como a proibição do culto às outras Divindades e ao uso de imagens.
} 
É bastante possível que estas denúncias dos profetas camponeses passaram a fazer parte das leis oficiais de Israel quando Jeú, apoiado pelo profeta Eliseu, massacra a dinastia de Amri e impóe o culto a Javé como o culto oficial no Israel norte (2Rs 10,16-28; cf. 1Rs 16,31-33). Possivelmente nessa ocasião o profeta Eliseu passou a fazer parte da corte de Jeú. Ou, mais tardar, nas reformas de Ezequias e de Josias.

E assim também se pode perceber com grande clareza o lado ambíguo da religiáo oficial: leis que na origem eram contra o acúmulo de riqueza e de poder realizado pela monarquia, quando integradas nas reformas eram postas a serviço da monarquia e visavam dar-lhe legitimidade.

\section{Refletindo...}

Isso também deve fazer-nos refletir como abordamos as outras religiōes e especialmente as que usam imagens. No Brasil, concretamente as religióes mais perseguidas por ostentarem esta característica são as religiôes afro-brasileiras. Também as religióes dos povos nativos, e as devoçóes católico-romanas, especialmente as de cunho popular.

A condenação destas religiôes, na maioria das vezes, está imbuída do mesmo espírito centralizador e imperialista que esteve presente nas reformas concentradoras de riqueza e de poder levadas a cabo por Ezequias e Josias, ou no mesmo espírito colonizador e imperialista pós-constatiniano que influenciou a constituição de parte importante das teologias, dos dogmas, das doutrinas e dos rituais das diversas correntes cristâs.

Que saibamos descolonizar nossas leituras bíblicas, nossas teologias e espiritualidades, despir nossas práticas religiosas de suas associaçóes presentes ou passadas com poderes colonizadores e imperiais e buscar dentro de nossa diversidade religiosa e cultural, o respeito, a convivência harmoniosa, para que dentro dessa mesma diversidade, possamos entender com profundidade o que seja adorar à Deus em "Espírito e verdade".

\section{Bibliografia}

Alonso Schökel, Luis (dir.). La Biblia de nuestro pueblo. Bilbao: Mensajero, 2006.

Bailão, Marcos Paulo. Shiloh. O messianismo antigo. São Paulo: Fonte Editorial, 2003.

Barton, John e Francesca Stavrakopoulou (eds.). Religious Diversity in Ancient Israel and Judah. London: T\&T Clark International, 2010.

Beale, G. K. Você se torna aquilo que adora. Uma teologia bíblica da idolatria. São Paulo: Vida Nova, 2014. 
Conferência Nacional dos Bispos do Brasil. Bíblia sagrada. Tradução da CNBB. São Paulo: Editoras Ave Maria-Santuário-Loyola-Vozes-Salesiana-Paulus-Paulinas, 2001.

De Vaux, Roland. Instituciones Del Antiguo Testamento. Barcelona: Herder, 1976.

Dietrich, Luiz José. "O 'Código da Aliança'. Revisitando textos e reavivando saudades”. Estudos Bíblicos Vol. 31, No. 123 (2014): 289-300. . "Quando Deus faz mal e mata”. Estudos Bíblicos Vol. 29, No. 116 (2012): 11-27.

Ediçôes Loyola. Bíblia. Tradução ecumênica. São Paulo: Loyola, 1997.

Editora Ave Maria. Bíblia sagrada Ave Maria. Edição de estudo. São Paulo: Ave Maria, 2011.

Editora Paulus. Bíblia de Jerusalém (nova edição, revista e ampliada). São Paulo: Paulus, 2002. . Nova Bíblia pastoral. São Paulo: Paulus, 2014.

Editora Vida Nova. Bíblia de estudo arqueológica NVI. São Paulo: Editora Vida, 2013. Finkelstein, Israel e Neil Asher Silbermann. A Bíblia não tinha razão. São Paulo: A Girafa Editora, 2004.

Gessenius, William. Hebrew-Chaldee Lexicon to the Old Testament (5a. reimpressão). Grand Rapids (MI): Baker Book House, 1982.

Holladay, William L. Léxico hebraico e aramaico do Antigo Testamento. São Paulo: Vida Nova, 2010.

Kaefer, José Ademar. "A Bíblia, a arqueologia e a história”. In Bíblia e cultura. Tradução e Exegese - debatendo as diferentes leituras da Bíblia. Conferências e ensaios apresentados no VI Congresso Brasileiro de Pesquisa Bíblica, compilado por M. Carneiro, 149-166. São Paulo: Fonte Editorial/ABIB, 2014. . "A estela de Dã". Revista Caminhando Vol. 17, 2 (2012): 33-46.

Kessler, Rainer. História social do Antigo Israel. São Paulo: Paulinas, 2009.

Koehler, Ludwig e Walter Baumgartner. The Hebrew \& Aramaic Lexicon of the Old Testament. The New Koehler-Baumgartner. Vol. 2. Leiden-Boston-Köln: Brill, 1995.

. The Hebrew \& Aramaic Lexicon of the Old Testament. The New KoehlerBaumgartner. Vol. 4. Leiden-Boston-Köln: Brill, 1999. 
Liverani, Mario. Para além da Bíblia. História antiga de Israel. São Paulo: Paulus/ Loyola, 2008.

Nácar, Eloíno e Alberto Colunga. Sagrada Biblia. Madrid: Biblioteca de Autores Cristianos, 1967.

Nocquet, Dany. El Dios único y los otros dioses. Esbozo de la evolución religiosa del antiguo Israel. Estella (Navarra): Verbo Divino, 2012.

Sacrosanti Oecumenici Concilii Vaticani II. Nova Vulgata. Bibliorum Sacrorum Editio. Vaticano: Libreria Editrice Vaticana, 2008.

Schniedewind, William M. Como a Bíblia tornou-se um livro. A textualização do Antigo Israel. São Paulo: Loyola, 2011.

Siegfried, Hermann. Historia de Israel en la época del Antiguo Testamento. Salamanca: Sigueme, 1985.

Silva, Airton José. "A história de Israel na pesquisa atual." In História de Israel e as pesquisas mais recentes, compilado por J. de Freitas Faria, 43-87. Petrópolis: Vozes, 2003. [Ver também o site deste autor: http://www.airtonjo.com].

Sociedad Bíblica de España y Sociedades Bíblicas Unidas. La Biblia del Siglo de Oro. Madrid: SBE-SBU, 2009.

Sociedade Bíblica do Brasil. Bíblia de estudo Almeida. Barueri: Sociedade Bíblica do Brasil, 2002.

Ubieta López, José Ángel (dir.). Biblia de Jerusalén. Nueva edición totalmente revisada. Bilbao: Desclée de Brouwer, 2009.

Zevit, Ziony. The Religions of Ancient Israel. A Synthesis of Parallactic Approaches. New York: Bloomsbury Academic, 2003. 